\title{
Emotional and Behavioural Difficulties Associated with Bullying and Cyberbullying
}

Bullying affects the lives of many children: some are victims, some take part in bullying others, and many are, to a greater or lesser extent, onlookers or witnesses of bullying behaviours. Usually seen as something that happens in schools and amongst peers, the advent of cyberbullying by mobile phones and via the internet, primarily in this century, has seen cases of bullying increase and traditional forms of the behaviour evolve.

This book considers the effects of bullying and cyberbullying on children. It looks at the different roles that are present within bullying and the different effects that it can have on a child's development of psychosomatic problems, self-esteem, friends and loneliness, school satisfaction, and family relations. It focuses on several key aspects of this type of intimidation and considers topics including traditional bullying, the situation of immigrant children in relation to bullying and victimization, cyberbullying in young people, and emotional and behavioural correlates of cyberbullying.

This book was originally published as a special issue of Emotional and Behavioural Difficulties.

Peter K. Smith is Emeritus Professor of Psychology at the Unit for Schooland Family Studies at Goldsmiths College, University of London, UK. His research interests are in social development, school bullying, play, and grandparenting. Previous publications include Children and Play (2010), Understanding Children's Development (2011) and Bullying in Schools: How Successful can Interventions be? (2004). 



\section{Emotional and Behavioural Difficulties Associated with Bullying and Cyberbullying}

Edited by

Peter K. Smith 
First published 2014

by Routledge

2 Park Square, Milton Park, Abingdon, Oxon, OX14 4RN

Simultaneously published in the USA and Canada

by Routledge

711 Third Avenue, New York, NY 10017

Routledge is an imprint of the Taylor \& Francis Group, an informa business

\section{(C) 2014 SEBDA}

All rights reserved. No part of this book may be reprinted or reproduced or utilised in any form or by any electronic, mechanical, or other means, now known or hereafter invented, including photocopying and recording, or in any information storage or retrieval system, without permission in writing from the publishers.

Trademark notice: Product or corporate names may be trademarks or registered trademarks, and are used only for identification and explanation without intent to infringe.

British Library Cataloguing in Publication Data

A catalogue record for this book is available from the British Library

ISBN13: 978-0-415-63498-4

Typeset in Times New Roman

by Taylor \& Francis Books

\section{Publisher's Note}

The publisher accepts responsibility for any inconsistencies that may have arisen during the conversion of this book from journal articles to book chapters, namely the possible inclusion of journal terminology.

\section{Disclaimer}

Every effort has been made to contact copyright holders for their permission to reprint material in this book. The publishers would be grateful to hear from any copyright holder who is not here acknowledged and will undertake to rectify any errors or omissions in future editions of this book. 


\section{Contents}

Citation Information vii

Introduction

Peter K. Smith

1. Listening to children's voices: moral emotional attributions in relation to primary school bullying Dawn Jennifer and Helen Cowie

2. Profiling social, emotional and behavioural difficulties of children involved in direct and indirect bullying behaviours

H. Smith, K. Polenik, S. Nakasita and A. P. Jones

3. Associations between types of involvement in bullying, friendships and mental health status Grace Skrzypiec, Phillip T. Slee, Helen Askell-Williams and Michael J. Lawson 34

4. Peer groups and victimisation among native and immigrant adolescents in Norway

Hildegunn Fandrem, Dagmar Strohmeier and Kolbrun Asta Jonsdottir

5. Emotional problems and victimisation among youth with national and international migration experience living in Austria and Turkey Dagmar Strohmeier and Aysun Dogan

6. From cyberbullying to electronic aggression: typology of the phenomenon Jacek Pyzalski

7. The perception of cyberbullying in adolescent victims Anna Ševčiková, David Šmahel and Mlada Otavová

8. Emotional and behavioural problems in the context of cyberbullying: a longitudinal study among German adolescents Anja Schultze-Krumbholz, Anne Jäkel, Martin Schultze and Herbert Scheithauer

9. Moral disengagement and emotional and social difficulties in bullying and cyberbullying: differences by participant role Sebastian Wachs

10. Cyberbullying victimisation in adolescence: relationships with loneliness and depressive mood

Dorit Olenik-Shemesh, Tali Heiman and Sigal Eden 


\section{CONTENTS}

11. Predictors of victimisation across direct bullying, indirect bullying and cyberbullying Antonella Brighi, Annalisa Guarini, Giannino Melotti, Silvia Galli and Maria Luisa Genta

12. Victims' perceptions of traditional and cyberbullying, and the psychosocial correlates of their victimisation Marilyn Campbell, Barbara Spears, Phillip Slee, Des Butler and Sally Kift

13. Peer victimisation and depressive symptoms: can specific coping strategies buffer the negative impact of cybervictimisation?

Katja Machmutow, Sonja Perren, Fabio Sticca and Françoise D. Alsaker

14. Does the association with psychosomatic health problems differ between cyberbullying and traditional bullying?

Linda Beckman, Curt Hagquist and Lisa Hellström

15. Problem behaviours, traditional bullying and cyberbullying among adolescents: longitudinal analyses 


\section{Citation Information}

The chapters in this book were originally published in Emotional and Behavioural Difficulties, volume 17, issue 3-4 (September-December 2012). When citing this material, please use the original page numbering for each article, as follows:

\section{Introduction}

Introduction

Peter K. Smith

Emotional and Behavioural Difficulties, volume 17, issue 3-4 (September-December 2012) pp. 223-227

\section{Chapter 1}

Listening to children's voices: moral emotional attributions in relation to primary school bullying

Dawn Jennifer and Helen Cowie

Emotional and Behavioural Difficulties, volume 17, issue 3-4 (September-December 2012) pp. 229-241

\section{Chapter 2}

Profiling social, emotional and behavioural difficulties of children involved in direct and indirect bullying behaviours

H. Smith, K. Polenik, S. Nakasita and A.P. Jones

Emotional and Behavioural Difficulties, volume 17, issue 3-4 (September-December 2012) pp. 243-257

\section{Chapter 3}

Associations between types of involvement in bullying, friendships and mental health status

Grace Skrzypiec, Phillip T. Slee, Helen Askell-Williams and Michael J. Lawson Emotional and Behavioural Difficulties, volume 17, issue 3-4 (September-December 2012) pp. 259-272

\section{Chapter 4}

Peer groups and victimisation among native and immigrant adolescents in Norway Hildegunn Fandrem, Dagmar Strohmeier and Kolbrun Asta Jonsdottir Emotional and Behavioural Difficulties, volume 17, issue 3-4 (September-December 2012) pp. $273-285$ 


\section{CITATION INFORMATION}

\section{Chapter 5}

Emotional problems and victimisation among youth with national and international migration experience living in Austria and Turkey

Dagmar Strohmeier and Aysun Dogan

Emotional and Behavioural Difficulties, volume 17, issue 3-4 (September-December 2012) pp. 287-304

\section{Chapter 6}

From cyberbullying to electronic aggression: typology of the phenomenon Jacek Pyżalski

Emotional and Behavioural Difficulties, volume 17, issue 3-4 (September-December 2012) pp. 305-317

\section{Chapter 7}

The perception of cyberbullying in adolescent victims

Anna Ševčíková, David Šmahel and Mlada Otavová

Emotional and Behavioural Difficulties, volume 17, issue 3-4 (September-December 2012) pp. 319-328

\section{Chapter 8}

Emotional and behavioural problems in the context of cyberbullying: a longitudinal study among German adolescents

Anja Schultze-Krumbholz, Anne Jäkel, Martin Schultze and Herbert Scheithauer Emotional and Behavioural Difficulties, volume 17, issue 3-4 (September-December 2012) pp. 329-345

\section{Chapter 9}

Moral disengagement and emotional and social difficulties in bullying and cyberbullying: differences by participant role

Sebastian Wachs

Emotional and Behavioural Difficulties, volume 17, issue 3-4 (September-December 2012) pp. $347-360$

\section{Chapter 10}

Cyberbullying victimisation in adolescence: relationships with loneliness and depressive mood

Dorit Olenik-Shemesh, Tali Heiman and Sigal Eden

Emotional and Behavioural Difficulties, volume 17, issue 3-4 (September-December 2012) pp. 361-374

\section{Chapter 11}

Predictors of victimisation across direct bullying, indirect bullying and cyberbullying Antonella Brighi, Annalisa Guarini, Giannino Melotti, Silvia Galli and Maria Luisa Genta

Emotional and Behavioural Difficulties, volume 17, issue 3-4 (September-December 2012) pp. 375-388 


\section{CITATION INFORMATION}

\section{Chapter 12}

Victims' perceptions of traditional and cyberbullying, and the psychosocial correlates of their victimisation

Marilyn Campbell, Barbara Spears, Phillip Slee, Des Butler and Sally Kift Emotional and Behavioural Difficulties, volume 17, issue 3-4 (September-December 2012) pp. 389-401

\section{Chapter 13}

Peer victimisation and depressive symptoms: can specific coping strategies buffer the negative impact of cybervictimisation?

Katja Machmutow, Sonja Perren, Fabio Sticca and Françoise D. Alsaker

Emotional and Behavioural Difficulties, volume 17, issue 3-4 (September-December 2012) pp. 403-420

\section{Chapter 14}

Does the association with psychosomatic health problems differ between cyberbullying and traditional bullying?

Linda Beckman, Curt Hagquist and Lisa Hellström

Emotional and Behavioural Difficulties, volume 17, issue 3-4 (September-December 2012) pp. 421-434

\section{Chapter 15}

Problem behaviours, traditional bullying and cyberbullying among adolescents:

longitudinal analyses

Leanne Lester, Donna Cross and Thérèse Shaw

Emotional and Behavioural Difficulties, volume 17, issue 3-4 (September-December 2012) pp. $435-447$ 